\title{
NOTAS ETNOGRÁFICAS SOBRE O RETRATO: REPENSANDO AS PRÁTICAS DE DOCUMEN- TAÇÃO FOTOGRÁFICA EM UMA EXPERIÊNCIA DE PRODUÇÃO COMPARTILHADA DAS IMAGENS
}

\author{
Fernanda Rechenberg ${ }^{1}$ \\ Universidade Federal de Alagoas, Maceió, AL, Brasil
}

\begin{abstract}
Este artigo discute o uso do retrato na antropologia com base em dados etnográficos de uma pesquisa antropológica realizada na cidade de Porto Alegre, RS. A partir da atuação em um projeto de elaboração de retratos de família no bairro Vila Jardim, aponto questões metodológicas sobre a produção de retratos na antropologia, e interpreto situaçóes etnográficas orientadas pela produção e observação de retratos, buscando trazer elementos para repensar as práticas de documentação fotográfica em contextos etnográficos.
\end{abstract}

Palavras-Chave: fotografia, retrato, família, Vila Jardim

Na história social da fotografia, o retrato despontou desde a produção das primeiras chapas fotográficas como a forma eleita para a representação de si associada à visibilidade de um processo de ascensão social, inclusive de camadas proletárias, com a popularização do carte-de-visite (Freund 1995). Por outro lado, com a captura da linguagem fotográfica pela ilusão do similar, os retratos fotográficos foram logo incorporados aos documentos de identificação e às fichas policiais. Sob a ótica de uma "antropologia criminal”, a fotografia foi desde sua invenção utilizada em prol do desvendamento de estereótipos identificados com a criminalidade (Fabris 2004; Martins 2011).

No período colonial, a violência das práticas que retratavam corpos e medidas orientadas pelos pressupostos de uma antropologia física, a espetacularização do exótico expressa nos retratos dos povos autóctones, a comercialização, a tipificação, o registro e o controle da imagem das populações escravizadas marcaram profundamente as relações entre o retrato e a antropologia. O retrato passou a significar aprisionamento: não apenas pelo incômodo/fascínio que a imagem miniaturizada e imóvel causava em quem a olhava (Benjamin 1994), mas pelo domínio avassa-

1 Contato: fernandarechenberg@gmail.com 
lador de discursos, muitas vezes científicos, impressos nos corpos destes sujeitos retratados em sua generalidade e anonimato.

Para o antropólogo David MacDougall (2006), no entanto, às relações comumente estabelecidas entre fotografia e etnografia as quais enfatizam uma espécie de clichê embasado nos primeiros contatos dos povos ditos primitivos com este aparato tecnológico, no qual o retrato assume um caráter essencialmente predatório, é possível acrescentar outro significado da fotografia: aquele que permite adicionar algo a nós mesmos e rever nossas diversas aparências. Ao invés de retirar algo do sujeito retratado, a fotografia poderia criar um exercício de desvendamento das possibilidades existentes dentro de nós (MacDougall 2006).

A possibilidade inventiva de reidentificação sugerida por MacDougall expõe o caráter ambivalente do retrato: transitando entre o efeito de realidade da presença e a ficção sugerida pela construção da pose, os retratos fotográficos expressam a um só tempo a comprovação e a invenção, o aprisionamento e a legitimação, o distanciamento e a proximidade.

Mesmo com seu indiscutível apelo testemunhal, o retrato não documenta o Outro, e sim uma interação que se desenrola em um contexto específico. Como afirma Sylvia Caiuby Novaes (2004), a presença da câmera já é um elemento que aciona a consciência da imagem exibida para o equipamento e seu operador. No retrato, não há captura do espontâneo, do incidental, não há flagrante: há uma relação documentada. Phillipe Dubois (1993) e Susan Sontag (2004) relacionam o retrato a uma inversão nas concepções de objetividade e autenticidade da imagem que "espelha" o referente: é através do artefato assumido enquanto tal que a pose constrói um realismo e uma autenticidade próprios de uma imagem convocada ${ }^{2}$.

É orientada por tais objeções e possibilidades que o presente artigo discute o retrato enquanto gênero fotográfico utilizado em contextos etnográficos. Pretende-se explorar as potencialidades interpretativas e metodológicas que o retrato oferece a partir de situações etnográficas emergentes durante a realização da pesquisa de doutorado ${ }^{3}$, especificamente no âmbito da atuação em um projeto de elaboração de retratos de família no bairro Vila Jardim, na cidade de Porto Alegre, RS.

\section{UM ESTÚdio na ViLa JaRdim}

$1^{\circ}$ de fevereiro de 2010, sábado pela manhã. O calor em Porto Alegre havia ultrapassado os $40^{\circ} \mathrm{C}$, eliminando os estoques dos aparelhos de ar-condicionado na cidade. $\mathrm{Na}$ casa quase sem janelas que sediava o Ponto de Cultura Ventre Livre 4 , o calor era ainda maior. Semanas antes, havíamos feito uma intensa e extensa divulgação pelas ruas, feiras, postos de saúde e casas na Vila Jardim. "Venha tirar o seu retrato", era a chamada dos panfletos entregues pelos integrantes do projeto e pelas crianças vizinhas ao ponto de cultura, que se tornaram nossas aliadas em

\footnotetext{
2 As observações de ambos os autores se referem aos retratos da fotógrafa norte-americana Diane Arbus.

3 Ver Rechenberg, Fernanda. Imagens e trajetos revelados: estudo antropológico sobre fotografia, memória e a circulação das imagens junto a famílias negras em Porto Alegre. Tese de Doutorado. Universidade Federal do Rio Grande do Sul. Instituto de Filosofia e Ciências Humanas. Programa de Pós Graduação em Antropologia Social., 2012. Disponível em: http://hdl.handle.net/10183/77135

4 Ponto de Cultura Ventre Livre (www.pontodeculturaventrelivre.blogspot.com).
} 
espalhar a notícia de que haveria um estúdio fotográfico onde os moradores poderiam "tirar" seus retratos gratuitamente.

Realizado em parceria com o Ponto de Cultura Ventre Livre, o projeto "Famílias do Jardim"5 oportunizaria uma das primeiras ações culturais no ponto de cultura, que à época estava se instalando na recém alugada sede e estabelecendo uma rede de relações entre os moradores do bairro. $\mathrm{O}$ projeto consistia em duas etapas: inicialmente, a produção de um estúdio fotográfico no Ponto de Cultura, aberto aos moradores durante dois dias, e num segundo momento, a produção de retratos de família no interior das casas dos moradores que se mostrassem disponíveis e interessados. Através de uma contínua negociação na produção e escolha das imagens, estas integrariam uma exposição fotográfica, um livro de retratos e um documentário sobre o projeto.

A heterogeneidade social característica da Vila Jardim era visível na paisagem descontínua do bairro, na coexistência de habitações próprias de uma classe baixíssima - os barracos de madeira e papelão situados nos becos - em ruas com grandes mansões muradas ${ }^{6}$. Nestes contrastes, o espaço das ruas era intensamente ocupado pelos moradores de camadas médias e baixas, os quais foram os mais receptivos à participação no projeto ${ }^{7}$.

Ainda que a gratuidade dos retratos adicionasse um componente atrativo aos moradores da vila, era a realização de um retrato individual por uma fotógrafa profissional que parecia conferir um estatuto diferenciado a estas fotografias. Muitos destes moradores, e especialmente os mais jovens, nunca haviam se visto retratados em uma fotografia em papel, ainda que alguns pudessem retratar e se verem retratados em outras mídias, principalmente nos telefones celulares, as quais armazenam imagens em memórias virtuais e raramente são impressas em papel.

Recebemos cerca de 70 pessoas ao longo dos dois dias de funcionamento do estúdio. Como fotógrafa do projeto, me inspirei nas técnicas dos retratistas de estúdios, tecendo breves diálogos com as pessoas que se posicionavam em frente à câmera, tentando criar um ambiente descontraído e provocando tímidos sorrisos. A sobriedade na qual a maioria dos retratados se portava diante da câmera informava sobre a formalidade que este momento representava. Muitos "clicks" eram necessários até que o desconforto e a intimidação que a presença da câmera e da iluminação provocava fossem atenuados, criando uma cumplicidade entre retratista e retratado própria de uma "câmera interativa" (MacDougall 2006), na qual a imagem captada é resultado de uma escolha pelo enquadramento das trocas e interações entre o fotógrafo e o sujeito fotografado.

5 "Famílias do Jardim" foi um dos projetos selecionados ao Prêmio Interações Estéticas 2010, promovido pela Fundação Nacional das Artes - FUNARTE, Ministério da Cultura - MINC. O projeto foi uma parceria entre Coletivo de Comunicação Catarse e Ponto de Cultura Ventre Livre.

6 Em frente ao Ponto de Cultura Ventre Livre, na Rua Galiléia, um grupo de crianças costumava brincar todos os dias na rua, diante dos altos muros de uma escola de elite, contrastando com as práticas de controle dos pais que levavam seus filhos da porta do carro até o interior da escola. Esta cena, que pude assistir semanalmente durante os meses do projeto, oferecia uma espécie de resumo da heterogeneidade social que caracterizava a Vila Jardim.

7 Por estarmos interessados em retratar justamente a diversidade de famílias residentes na vila, fizemos uma ampla divulgação para que o maior número de pessoas pudesse saber da existência do projeto. Efetivamente, as famílias com quem tivemos contato eram de classe média, baixa ou baixíssima. Embora tentássemos contato com famílias de classe média e alta, deixando folhetos nas caixas de correspondência e conversando brevemente nas portas de suas casas, não tivemos muito retorno às nossas investidas de diálogo. Os moradores de classe média e alta raramente eram encontrados na rua, espaço onde circulávamos com frequência. 
Situar os sujeitos os quais retratei no estúdio fotográfico diante da câmera e de uma iluminação que os colocava no foco das atenções, era tanto uma situação inusitada que trazia uma dose de desconforto, como uma ocasião para se construir a imagem de si em um processo criativo, inventivo, e que muitas vezes ficcionalizava ou encontrava novas potencialidades para a expressão de uma identidade por meio do retrato.

Alguns recursos simbólicos ${ }^{8}$ utilizados neste processo de configuração da imagem de si estavam disponíveis no estúdio improvisado: organizamos um camarim, com espelho, lenços para secar o suor, roupas e acessórios diversos. Foi principalmente no segundo dia de funcionamento do estúdio que os moradores se sentiram mais a vontade para levarem pertences ou vestimentas de casa, enfatizando uma identidade individual ou coletiva associada à simbólica dos acessórios que eram trazidos ao retrato. $\mathrm{O}$ que estava em jogo no uso destes recursos era como, o quê ou quem se escolhia na composição desta imagem. A vestimenta escolhida para o ato fotográfico, como pontua Annateresa Fabris, enfatiza um ato de diferenciação e singularidade, tornando visíveis clivagens, hierarquias e solidariedades através da combinação de elementos selecionados de acordo com certas regras e códigos estabelecidos pela sociedade (Fabris 2004).

As amizades, os amores e os laços de parentesco constituíram algumas das composições escolhidas para falar de si, em relação ao outro, amigo(a), namorado(a), marido, esposa, filhos(as), netos(as). Tais moradores mostravam que na elaboração desta imagem que guardaria na memória a expressão de si, as relações de sociabilidade e os vínculos afetivos assumiam um lugar privilegiado. Expressar a si mesmo em um retrato era também expressar o seu lugar em um conjunto de pertenças simbólicas e relações afetivas, perpetuando através da fotografia relações duradouras e mesmo efêmeras.

8 David MacDougall (2006) denomina "symbolic props" os recursos comumente utilizados nos primeiros retratos fotográficos, tais como vestimentas, pertences e livros. No contexto deste trabalho, me refiro tanto a objetos, vestimentas, cenários como a outras pessoas que auxiliam na construção simbólica desta identidade fotograficamente representada. 


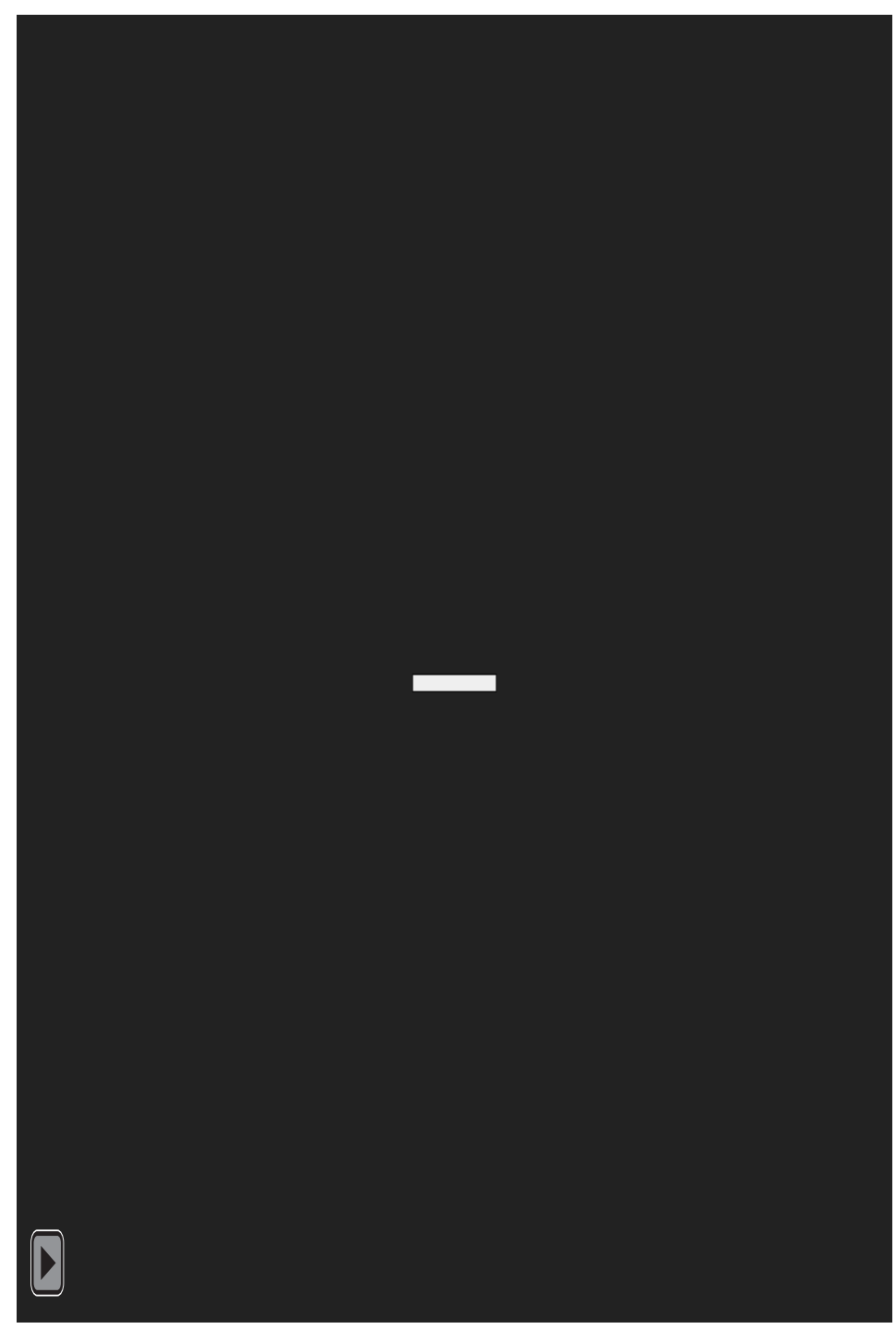

Fotografias da autora.

No final semana seguinte à realização dos retratos, montamos uma espécie de banca em frente ao ponto de cultura onde os retratos eram entregues. Muitos moradores que haviam sido retratados compareceram, outros deixaram suas imagens conosco, fazendo-nos percorrer ruas e becos em busca de seus endereços na Vila nas semanas seguintes, para entregar as fotografias. Neste percurso, fomos aos poucos encontrando as famílias que abririam as portas de suas casas para um contato mais prolongado, para pensarem suas famílias, para se debruçarem sob um conjunto de memórias, afetos e experiências vividas que envolveriam a criação de um retrato de família.

\section{O retrato, as casas, as famílias}

Subindo e descendo ladeiras, insistindo na procura de endereços inexistentes informados por crianças desacompanhadas, encontrando moradores alcoolizados e com feições muito distintas dos sorrisos emoldurados de semanas atrás, tendo, por vezes, diálogos não muito amigáveis com os pais das crianças retratadas no estúdio, foi com espanto que reencontrei estes adultos, jovens e crianças em suas casas, muitos deles despenteados, sujos e com roupas rasgadas. 
Guardando em minha lembrança as imagens que havia retratado no estúdio fotográfico, tive dificuldade em reconhecê-los neste novo contexto que para mim se apresentava: o de suas vidas cotidianas.

Ao observar os homens, mulheres e crianças os quais havia retratado no estúdio, não mais isolados de seus cenários cotidianos, mas plenamente inseridos nos contextos sociais e familiares, nas paisagens urbanas e nas moradias em que habitavam, pude perceber como as fotografias realizadas em estúdio haviam oportunizado o retrato do excepcional e de tudo aquilo que atestava contra a dureza do cotidiano. Os investimentos em torno da própria imagem que seria retratada em uma situação excepcional expressavam o valor atribuído à aparência externa e à apresentação pessoal, o qual poderia constituir uma "forma-antídoto" de enfrentamento do cotidiano (Martins 2011). Retratar o ócio, os afetos, as fantasias, as encenações, mostrava não apenas a vontade de perpetuar uma imagem do não ordinário, mas um desejo de contemplar, na constituição de uma representação fotográfica de si, um "querer-ser", uma identidade prenhe de projetos e fantasias.

Se os retratos produzidos no estúdio fotográfico proporcionaram um descolamento da vida rotineira, na construção do retrato familiar a imagem a ser projetada pelos sujeitos era inseparável de seu contexto cotidiano. Ainda assim, a proposição de realização deste retrato fotográfico, e os sucessivos encontros, conversas e preparativos daí decorrentes desencadeavam uma ruptura no movimento ordinário da vida cotidiana pela instauração de um momento de reflexividade. O significado da família, os conflitos, as tensões, a biografia familiar emergiam de forma mais ou menos intensa nos encontros.

A produção dos retratos, portanto, conformava um "drama" significativo em torno das vivências familiares. Ainda que o retrato não fuja à regra fotográfica de constituir uma cena captada em um instante, todos os investimentos e preparativos em torno da produção desta fotografia deixavam claro que não era possível pensar no retrato de família como um ato de congelamento da realidade familiar, como um instantâneo que cristalizava a ação do tempo. $\mathrm{O}$ tempo decorrido na realização destes retratos de família, que poderia durar minutos, horas e até semanas no caso dos acordos e negociações familiares necessários para que todos estivessem presentes, situava a fotografia mais como um acúmulo de investimentos e afetos individuais e familiares que culminavam na realização do retrato.

Ao centrarmos nossas abordagens em campo nos enquadres da "família" e da "fotografia", explicitávamos uma deferência e um valor relacional entre estes campos de significado, aderindo a uma estética de longa duração do retrato de família, a qual estabelece uma relação entre o "retrato", a "família", a "casa”. Tais relações expressam um conjunto de valores simbólicos associados na representação do eu, tributário a um imaginário que vincula as representações familiares ao espaço da casa, como assinalou o trabalho de Miriam Moreira Leite (1993) sobre retratos de famílias de imigrantes no sudeste brasileiro.

Embora esse tipo de retrato expresse um código que associa a família a uma instituição solenemente reafirmada na ocasião da fotografia, como forma de tornar pública a trama bem urdida da harmonia e coesão familiar, diversas famílias se recusaram a nos receber, ou o fizeram com muito receio, mostrando que os espaços íntimos e muitas vezes dramáticos das vivências familiares não seriam compartilhados com estranhos. 
Nossa entrada nas casas tornava premente o reconhecimento da existência de "códigos de visualidade" (Martins 2011) enquanto categorias nativas capazes de mediar a relação entre o fotógrafo e sua câmera e o sujeito fotografado, informando condições e restrições à captação de sua imagem. A valorização das interlocuções que tínhamos com cada família na tentativa de construir conjuntamente o retrato baseava-se no pressuposto de que, para além das cenas e aspectos que visualmente eram atrativos na perspectiva de um olhar antropológico, o que estava em jogo era a centralidade das categorias de construção visual de si destas famílias para a composição do retrato. Nesse sentido, na contramão de uma conduta que investiga visualmente a paisagem e o corpo alheio com base em categorias antropológicas e frequentemente tributárias a uma tradição documental na captura das imagens, privilegiei o retrato dos elementos que eram destacados pelas famílias como relevantes na produção de um retrato familiar. $O$ fato de a captura das imagens acontecer no âmbito privado das casas destas famílias tornava ainda mais premente reconhecer as permissões e interdições do olhar alheio na vida íntima e cotidiana.

Este mote fotográfico também proporcionava uma oportunidade reflexiva na pesquisa antropológica com imagens, em que cada encontro com as respectivas famílias constituía uma ocasião "boa para pensar" as interlocuções necessárias para produção de imagens compartilhadas. Minha atuação como fotógrafa e agente de uma política cultural em um contexto nacional de valorização do "popular", do "periférico", do "étnico", e de "resgate" de memórias silenciadas, fez com que o olhar "de perto e de dentro" que buscávamos compor ao retratar estas famílias em um processo colaborativo e compartilhado fosse re-situado no agenciamento de propostas discursivas de éticas diferenciadas. A ação social proposta pelo projeto produzia o encontro de uma meso-ética através de uma política cultural mediada por um grupo de profissionais e suas respectivas éticas de atuação na vida social, com uma micro-ética própria dos agenciamentos cotidianos dos moradores da Vila Jardim em suas lógicas de habitar, conviver, lembrar9.

Na perspectiva de uma "antropologia compartilhada" não tínhamos como objetivo apenas estabelecer as condições de uma reciprocidade que se materializava através da entrega de fotografias para "ganhar a confiança do nativo", criando a necessária aceitabilidade da presença do antropólogo diante do grupo para a concretização da pesquisa. O planejamento e a estrutura geral do projeto propositalmente encadeavam ações de reciprocidade entre as etapas sem as quais o projeto fracassaria. Isso significava que as tensões, os conflitos, as situações imprevistas e inesperadas tinham que ser negociadas no cenário de uma relação que só podia se desenrolar se houvesse reciprocidade de ambas as partes.

A aceitação da continuidade deste vínculo por parte destas famílias fez com que compartilhássemos escolhas na produção do retrato fotográfico, o que envolveu um processo de negociação entre as minhas preferências estéticas e narrativas na composição da imagem, e as preferências da família em relação à escolha do local, dos participantes da fotografia, do enquadramento, da luz e da composição.

9 Os conceitos de micro e meso-ética são aqui utilizados segundo as reflexões de Roberto Cardoso de Oliveira (1996) acerca das intersecções entre o saber e a ação social, reconhecendo a existência de éticas diferenciadas. 


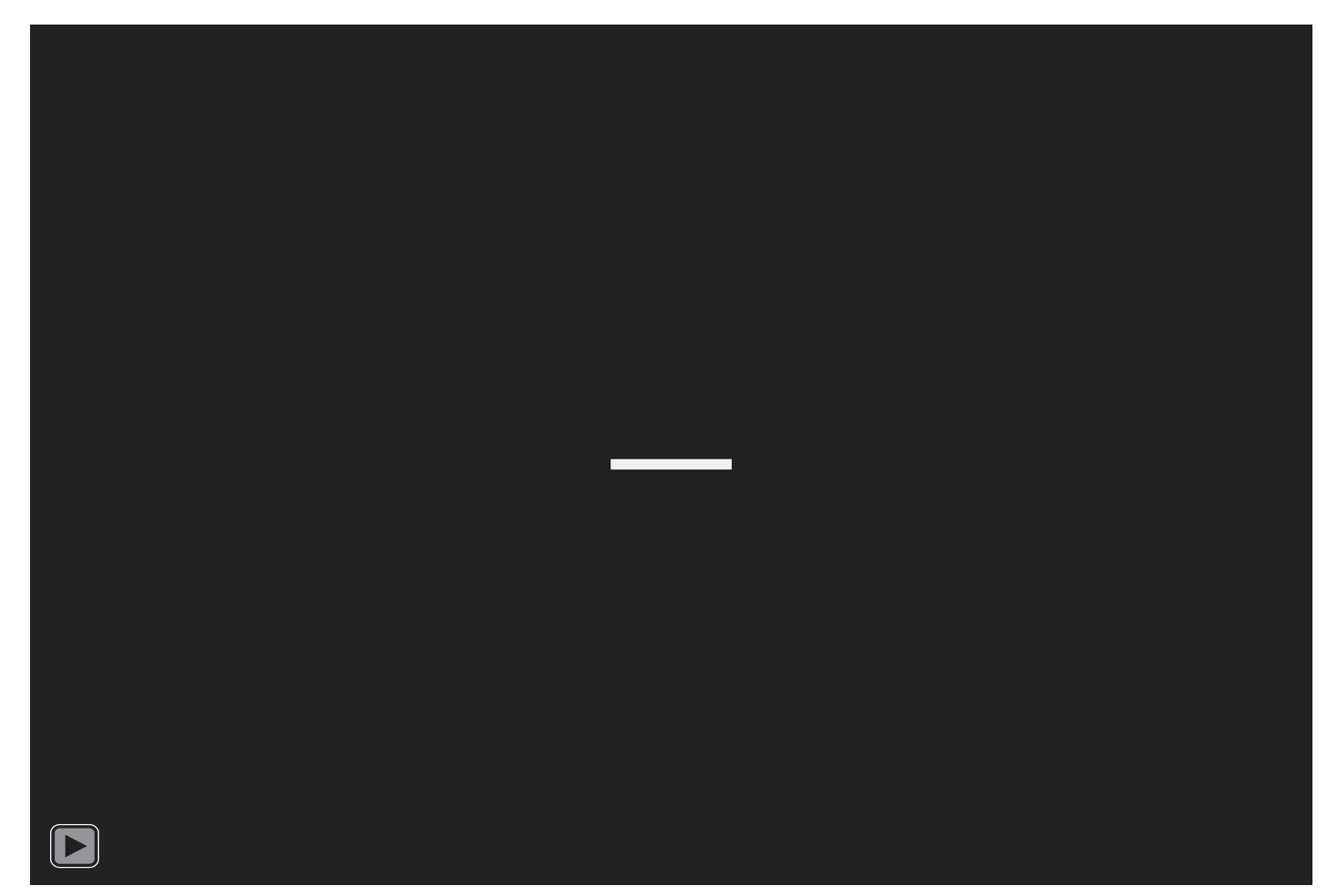

Fotografias da autora.

\section{De Retratos E SITUAÇões ETNOGRÁfICAS: REPENSANDO PRÁtICAS DE DOCUMENTAÇÃo FOTOGRÁ- FICA}

Após ser retratada junto a seus dois filhos no estúdio fotográfico, Ediane retornou na semana seguinte ao Ponto de Cultura para buscar seu retrato. Lá, conversamos animadamente sobre a fotografia, a Vila Jardim e as muitas ideias que ela tinha para ajudar outros moradores do bairro, especialmente os mais jovens. Ediane dizia ter se identificado com o nosso trabalho. Esta identificação com algo que era "diferente", que alterava a rotina do bairro, foi, segundo ela, o principal atrativo para que ela aceitasse a realização de um retrato familiar em sua casa.

Encontrar a casa de Ediane, na parte baixa da Rua São Leopoldo, onde dezenas de casas eram identificadas como "os fundos do número 163", não foi uma tarefa fácil. Ela morava ao fundo da casa de seu avô, em um dos muitos "becos" da Vila Jardim, com seu segundo marido e seus dois filhos. Fizemos vários contatos telefônicos, nos quais ela sempre se mostrava entusiasmada para nos receber em sua casa. Sua casa tinha apenas três cômodos: a sala/cozinha, um quarto onde todos dormiam e o banheiro. Para fazer a fotografia na sala, tive que me posicionar do lado de fora da casa, na porta ou no beiral da janela de modo a enquadrá-los. Esta pequena casa em que habitava, significava para Ediane a constituição de uma nova família.

Ao olharem as fotografias feitas em sua casa, Ediane e o marido propunham interpretações acerca das imagens a partir de experiências biográficas e do cotidiano, mas também de um repertório visual capaz de associar o modo através do qual uma pessoa é retratada e seu estatuto social. Uma das fotografias, que havia sido escolhida pelo casal para ser ampliada em tamanho 
grande, retratava o que ela chamou de "humildade" da família:

Ediane: A gente até brinca aqui em casa quando a gente olha essas foto, que nós somo muito humilde, saiu todo mundo de pé descalço. [risos] A família dos humilde!

Jocosamente, Ediane evocava toda uma história social do retrato marcada por segregações e distinções sociais. Ao final do século XIX, quando a fotografia se fazia anunciar como um equipamento protótipo da modernidade, as famílias abastadas vestiam suas melhores roupas a exemplo dos retratos pictóricos da nobreza europeia. Apenas os escravos eram fotografados de pés descalços. Embora Ediane e o marido tenham se disposto em frente à câmera sem sapatos nem chinelos na ocasião do retrato, e tenham escolhido justamente a fotografia que enquadrava seus pés descalços, a relação entre humildade e ausência de sapatos não passou despercebida. Em outra fotografia, que retratava os quatro na janela, Ediane e o marido se referiam ao momento em que eles "esperavam o resgate" de uma enchente imaginária que inundaria o vulnerável beco em que habitavam.

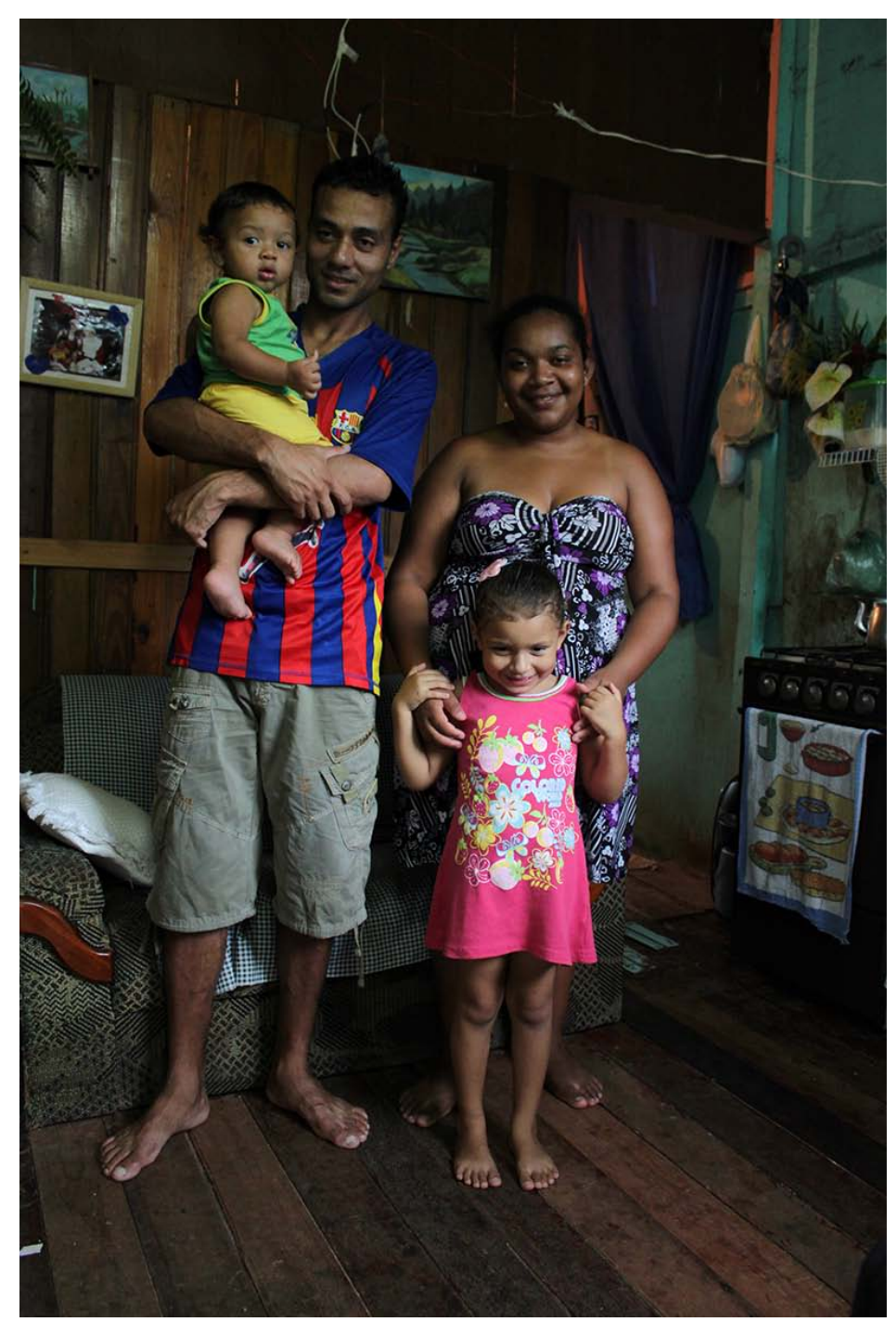

“A família dos humildes". Família de Ediane e Rodrigo. Vila Jardim, 2010. Fotografia da autora. 


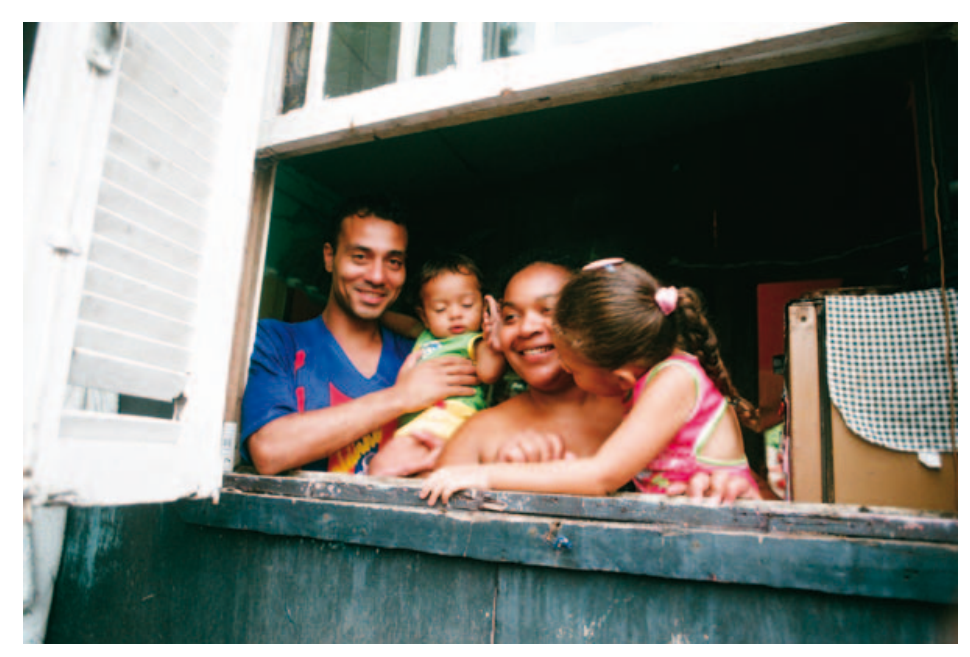

"Esperando o resgate". Família de Ediane e Rodrigo. Vila Jardim, 2010. Fotografia da autora.

Ao tecer esses comentários, Ediane nos fazia ver a existência de um olhar etnocêntrico e eurocêntrico que está na ontologia da captura fotográfica, e que perdura no entrelaçamento temporal das formas de ver e retratar o Outro. Não é possível retratar estes moradores sem carregar no dispositivo e no olhar, o peso de uma história social do retrato que é densa de exclusões, segregações e padrões de diferenciação na documentação de sujeitos os quais aparecem diferentemente nas fotografias. Se por um lado, Ediane considerava positivo dar visibilidade a seu cotidiano, mostrando um pouco do seu dia a dia e das condições pelas quais ela passava, por outro, ser retratada em sua humilde casa, sem sapatos, reforçava o registro da imagem das condições de vida que tornavam seu cotidiano tão áspero.

Já as fotografias que haviam sido realizadas no Ponto de Cultura pareciam retirar estes moradores de seus cenários cotidianos, apontando para as possibilidades de construção momentânea de uma identidade liberada da imagem do "pobre descalço". Estas eram as fotografias preferenciais para serem dispostas nos porta-retratos e nas paredes das salas que recebiam as visitas, como pude notar nos momentos subsequentes à realização dos retratos, quando entrava nas casas destes moradores. As fotografias de Ediane e de seus filhos feitas no estúdio foram disputadas entre seus familiares:

Ediane: Uma eu tive que dar pra sogra de presente, senão bate aquele ciúmes... uma eu dei pra minha mãe, e a outra pra minha cunhada. Ah, e outra pra minha irmã. Aí [...] a minha mãe disse assim, nossa, vocês foram no estúdio? Eu falei, não, a gente fez ali no ponto ali, de cultura, ali. Aí ela bem assim: ah, ta, me empresta então que eu vou tirar xerox pra mim. Até hoje to esperando a minha foto. Eu digo ta, mãe, faz o seguinte, como eu ganhei duas eu dou uma pra sogra e a outra fica pra senhora.

A reação dos familiares diante de uma inusitada fotografia de estúdio e o desejo de guardarem para si os retratos de outrem mostrava o circuito percorrido por estas imagens em um âmbito familiar. Possuir a imagem do outro a quem se destinava um afeto era mais importante do que a nitidez ou resolução fotográfica da imagem: a fotocópia era um recurso alternativo que possibilitava a reprodução da imagem a um baixo custo e com relativa autonomia do fotógrafo que a produziu. 


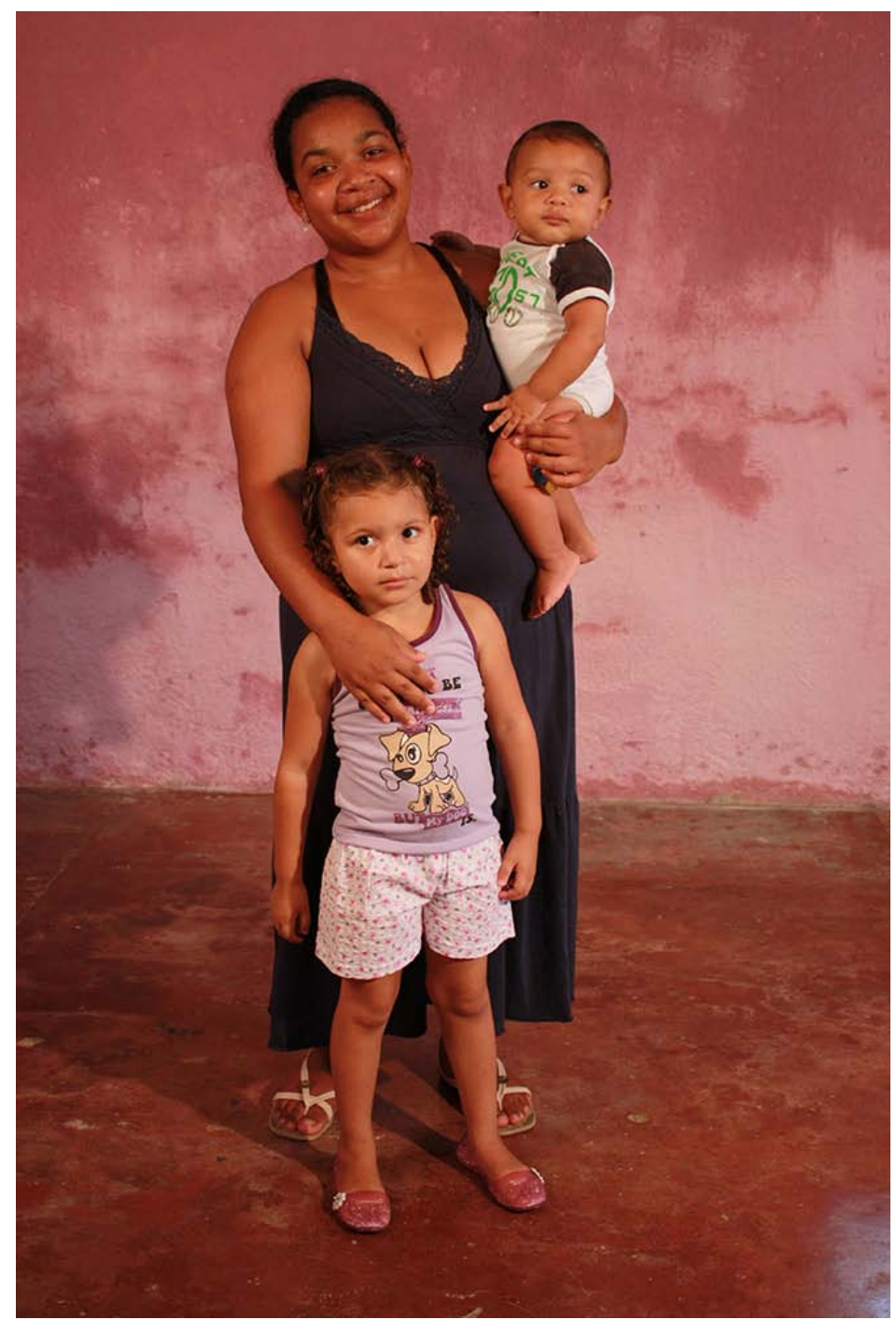

Retrato de Ediane Machado da Silva, Vithor Esequiel Silva e Izayane Gabriele Santos da Silva. Vila Jardim, fevereiro de 2010.

Fotografia da autora.

Reconhecer a existência de um código de visualidade por parte destes moradores os quais, assim como eu, partilhavam de uma cultura visual e nela inscreviam suas experiências cotidianas, suas trajetórias biográficas, o "ethos" particular de suas pertenças territoriais, religiosas, étnicas, etc, tornou-se não apenas a condição para o desenrolar do trabalho, mas proporcionou a investigação de um campo de produção de sentidos na atribuição das identidades de si e do outro.

Tais códigos estão muito ligados à produção de imagens destas famílias e à construção de seus acervos particulares - e todos os processos de lembrança e esquecimento implicados na guarda, no descarte e nos esconderijos que preservam certas fotografias à distância do olhar cotidiano.

Paulo Cezar era entregador de jornais e chefe de uma extensa família de oito filhos e dez netos. Conheci-o através de seu extrovertido filho, em um dos becos da Vila Jardim. Conversamos diversas vezes pelo telefone até conseguirmos marcar uma data para a realização do retrato em família. Por telefone, ele se mostrava muito animado com a ideia, e todos os familiares corroboravam em dizer que ele gostava muito de fotografia e fazia questão de reunir a numerosa família 
para este momento. Falava pouco, e por isso o contato mais prolongado aconteceu principalmente com sua esposa e sua filha.

Muitos dos momentos do casal e de todos os filhos e netos, irmãos e sobrinhos, estavam retratados nas fotografias dispostas em um mural na sala. Ali, convites de aniversário, fotografias recentes e fotos de até 20 anos atrás encadeavam uma narrativa familiar por imagens. A fotografia era um gosto particular de Paulo Cezar. Mesmo com as dificuldades financeiras que envolvem a criação de oito filhos, o casal colocava em prioridade o registro fotográfico da vida familiar, como contou sua filha Shaina:

Shaina: Aniversário aqui tem que ter foto! Se não tiver foto, deu, ele fica brabo. Não tem aniversário! Pode ter um prato de arroz e feijão pra gente comemorar, mas tem que ter a foto. A foto não pode faltar. É mais essencial do que o bolo.

No Natal, Paulo Cezar levava os filhos ao shopping-center para fazer as conhecidas fotografias de crianças junto ao velho senhor vestido de Papai Noel, inserindo sua família em um território o qual, embora geograficamente próximo a sua casa, destinava-se às famílias de camadas médias e altas com poder de consumo dos produtos de preço elevado, expostos nas vitrines das lojas.

Esta encenação proporcionada pelo retrato expressa uma tática de subversão de fronteiras, na qual a fotografia testemunha como próximo e integrado aquilo que é socialmente distante e segregado. A esposa e a filha de Paulo Cezar, ao contarem as situações armadas por ele para fotografar a família, mostravam como a fotografia oferecia uma possibilidade de burlar uma fronteira de classe:

Shaina: A gente adorava tirar foto quando era criança. Meu pai sempre acostumou a gente assim, o tempo inteiro. A gente passava nos bairros chiques, meu pai parava na frente das casas bonitas pra tirar foto. Pra depois mais tarde se exibir como se a casa fosse dele!

Jussara: Ah, é, lá na praia também, né Shaina, tiraram na frente de um edifício assim, enorme: "ah, onde é que vocês tavam?” "Nós tava aí!" Que, tava aí, nada [risos].

Vemos como as fotografias de Paulo Cezar a um só tempo aderiam e subvertiam as convenções historicamente sedimentadas que documentam a hierarquia social da família em um arquétipo de classe, como mostram inúmeras fotografias de famílias de elite no século XIX e início e meados do século XX. A ênfase destas fotografias não estava na captura dos laços afetivos que uniam os familiares. Mais do que isso, estas imagens primavam em mostrar as vestes, acessórios, cenários, e outros recursos simbólicos como forma de documentar a crescente participação da vida doméstica na instância pública, mas de uma vida privada "mostrável" cujo caráter público visava a legitimação e a demarcação de fronteiras sociais.

As fotografias de Paulo Cezar pareciam tanto fabular uma realidade inexistente quanto materializar em sua característica testemunhal as aspirações de uma ascensão social pouco provável. Fotografar sua esposa e filhos em frente a prédios chiques e casas grandes na praia expressava, jocosamente, uma possível fluidez nos limites que separam as distintas classes e grupos sociais, transgredindo as linhas imaginárias que mantêm cada um no lugar que lhe é próprio. 
A fotografia, neste caso, entrelaçava as possibilidades de testemunho - e portanto, veracidade - e imaginação, podendo ficcionalizar e materializar um campo de possibilidades, na representação fotográfica, acerca de projetos de ascensão desejados. Ao associar pessoas de classe popular com habitações de elite, a produção destas fotografias subverte fronteiras simbólicas e materiais sob a sugestão da verossimilhança que caracteriza o dispositivo fotográfico. É justamente a potência de irrealidade proporcionada pela fotografia que permite ao fotógrafo amador uma experimentação nas representações de si diante de cenários e contextos extraordinários.

As fotografias e as práticas do fotografar são, para usar uma expressão cara ao pensamento antropológico, "boas para pensar". "Boas", por revelarem valores e motivações implícitos em uma prática cultural de representação de si, "boas" como um campo privilegiado para o estudo da memória e das aspirações ao devir que a pose projeta ao futuro, "boas" para pensar a relação entre a classe social, raça, poder econômico e político, e o controle que os sujeitos retratados tinham e têm sobre a produção e circulação de suas imagens.

Se, no campo dos estudos da imagem, diversos pensadores vêm insistindo na "desmontagem" do efeito de realidade proporcionado pela fotografia (Soulages 2012; Kossoy 2002 2007; Fatorelli 2003; Machado 1984) cabe à Antropologia pensar em que medida as situações etnográficas incitam reflexões acerca do caráter de veracidade atribuído à fotografia pelos próprios antropólogos. Para José de Souza Martins, a imagem na sociologia e na antropologia ainda depende de um "conformismo factual" que a torne documental, ou seja, que atribua a ela um valor de interesse científico (Martins 2011).

Ao refletir sobre o que seria um "problema incontornável" da fotografia, François Soulages (2010) pergunta acerca dos motivos pelos quais insistimos em acreditar na exatidão dos acontecimentos retratados, conferindo à fotografia o estatuto de prova da existência efetiva de um acontecimento. Para o autor, a doutrina do "isto existiu" proclamada por Roland Barthes ganha proporções mitológicas no campo das reflexões sobre a fotografia. Para Soulages, o dito "isto foi encenado" traduziria melhor a natureza da fotografia.

No campo dos estudos de imagem na Antropologia, a potência que encobre este "problema incontornável" na fotografia pode estar justamente neste jogo entre realidade e ficção, habilmente compreendido por muitos fotógrafos amadores e profissionais menos comprometidos com a manutenção de um estatuto de verdade à fotografia. Trata-se de compreender que a existência de uma cena registrada pela câmera não constitui um documento da factualidade social, mas sim de todo um imaginário associado a ela (Martins 2011). É nesta perspectiva que o retrato fotográfico enquanto recurso etnográfico traz em si uma potência capaz de subverter, pela força de um realismo que é apenas aparente, a própria crença do antropólogo na autenticidade de seus registros visuais.

\section{REFERÊNCIAS}

Benjamin, Walter. 1994. "Pequena história da fotografia". Magia e técnica, arte e politica. São Paulo: Brasiliense.

Caiuby, Sylvia. 2004. "Imagem em foco nas Ciências Sociais”. In: Caiuby Novaes S.; Barbosa A.; Cunha E.; Ferrari, F.; Sztutman R. e Hikiji, Rose Satiko. (Org.). Escrituras da Imagem. 
São Paulo: EDUSP \& FAPESP, p. 11-18.

Cardoso de Oliveira, R.; Cardoso de Oliveira, L. R. 1996. Ensaios antropológicos sobre moral e ética. Rio de Janeiro: Tempo Brasileiro.

Dubois, Phillipe. 1993. O ato fotográfico e outros ensaios. Campinas, SP: Papirus.

Fabris, Annateresa. , 2004. Identidades Virtuais: uma leitura do retrato fotográfico. Belo Horizonte: Editora UFMG.

Fatorelli, Antônio. 2003. Fotografia e viagem: entre a natureza e o artifício. Rio de Janeiro: Reluma-Dumará.

Freund, Gisèle. 1995. Fotografia e Sociedade. 2a edição. Lisboa: Vega.

Kossoy, Boris. 2007. Os Tempos da Fotografia. O Efêmero e o Perpétuo. Cotia, SP: Ateliê Editorial. . 2002. Realidades e fições na trama fotográfica. São Paulo: Ateliê Editorial.

Leite, Miriam Lifchitz Moreira. 1993. Retratos de família: leitura da fotografia histórica. São Paulo: Editora da Universidade de São Paulo.

MacDougall, David. 2006. The Corporeal Image. Film, Ethnography and the Senses. Princeton, New Jersey: Princeton University Press.

Machado, Arlindo. 1984. A ilusão especular. Introdução à fotografia. São Paulo: Brasiliense.

Martins, José de Souza. 2011. Sociologia da Fotografia e da Imagem. São Paulo: Contexto.

Sontag, Susan. 2004. Sobre fotografia. São Paulo: Companhia das Letras.

Soulages, François. 2010. Estética da fotografia. Perda e permanência. São Paulo: Editora SENAC São Paulo.

\section{ETHNOGRAPHIC NOTES ON PORTRAIT: RETHINKING PHOTOGRAPHIC DOCUMENTATION PRACTICES IN A SHARED VISUAL IMAGE PRODUCTION EXPERIENCE}

This article discusses ways of using portrait in anthropology, based on an anthropological research in Porto Alegre, RS, Brazil. Ethnographic data from a photographic documentation project of families from Vila Jardim neighbourhood are used to discuss methodological issues about the use of portrait in anthropology and the interpretation of ethnographic situations, suggesting a new view of photographic documentation practices within ethnographic settings.

Keywords: photography, portrait, family, Vila Jardim

Recebido em: 2014-01-28

Aceito em: 2014-06-13 